graphic films and plates when used with an optical system as near perfect as possible; a study has also been commenced to obtain quantitative data on the dimensional accuracy and resolution of the multiplex system of photogrammetry.

The Maritime Regional Laboratory, Halifax, opened officially on June 16, 1952, plans at first to pursue investigations on fundamental and applied aspects of the commoner seaweeds of the Maritime Provinces. The Division of Medical Research made 162 grants for experimental projects, including thirteen for investigations in bacteriology and antibiotics; twenty for research in anatomy, histology, development and ageing; thirty-six for work on biochemical and metabolic problems in normal and pathological processes; and fifty-two for studies in physiology, pathology, pharmacology and surgery. The Division of Building Research continued to study heat and moisture problems in house walls, and by the spring of 1953 expected to have seven outside corrosiontest sites in operation across Canada, while much time has been spent on fundamental studies of the treatment of fire protective measures in building codes. The Division of Mechanical Engineering has developed a small semi-diesel marine engine with a reversible propeller for inshore fishing boats; besides studies in the gas-turbine field, on structural fatigue, and on heat transfer at high rates from metals to liquids, it is continuing its comprehensive investigation of aircraft de-icing. In the Division of Radio and Electrical Engineering, where defence projects still comprise the major part of the work, a notable contribution has been made in the extension of the theory of slotted wave-guide arrays, which will result in smaller radar antennæ and clear radar pictures in merchant marine applications.

\section{MIGRATION FROM BRITAIN SINCE 1815}

A

S a compilation of the available statistics relating to external migration since 1815 , economists and others interested will welcome a publication on the subject from the General Register Office, written by M. H. Carrier and J. R. Jeffery*. Relevant statistics from the Censuses, the records of the Colonial Land and Emigration Commission, the Board of Trade, Home Office and National Register have been brought together, with useful notes on their scope and limitations. So far as possible, the migrants are classified according to country of origin and destination, age, sex, marital state and occupation.

The data provide almost a text-book illustration of the 'undesigned' nature of most British economic statistics. They are, in fact, almost entirely byproducts of administrative activity and not the outcome of attempts to measure directly the volume of migration. The figures for 1815-42, for example, are derived from the muster rolls of the ships leaving British ports, the administrative purpose of which was to ensure that the vessels carried sufficient food and drink. For this reason alone, these statistics distinguish between children and adults. Neverthe. less, the authors have found it possible to present in broad outline an account of emigration from the United Kingdom since 1815, and of changes in * General Register Office. Studies in Medical and Population Subjects : No. 6, External Migration, a Study of the Available Statistics, 1815-1950. By M. H. Carrier and J. R. Jeffery. Pp. 163. (London: H.M.S.O., 1953.) 88. $6 d$. the type of person emigrating. The great volume of emigration is demonstrated: more than twenty million persons are supposed to have left the United Kingdom as emigrants during the nineteenth century. The discussion of the short-term fluctuations in the number of emigrants includes a survey of the changing attitudes of official and unofficial opinion to the emigration question and of various schemes for assisting or controlling it.

A complete account of this topic would involve an extensive discussion of the shifts since the beginning of the nineteenth century in public opinion on the population problem in general, and would have taken the authors far beyond the immediate scope of their paper. It must, however, be said that the discussion of the economic factors involved is superficial. The diagram on p. 21 does not seem to bear out in detail the simple 'repulsion' explanation of emigration to which in the last resort the authors subscribe. The curve of emigration seems frequently to reach its peaks several years after acute economic depressions, so as to attenuate the correlation between the volume of emigration and the level of economic activity. Similarly, emigration from Ireland did not reach its peak until four years after the potato famine of 1846-48. An adequate explanation of fluctuations in the volume of emigration would have to take into account a great many factors, including changes in the volume of British investment in the New World.

It is perhaps unfortunate that, unwilling to embark on such a complete account of the subject, the authors have not limited themselves strictly to com. piling a statistical source-book. The production of the paper is deplorable. The use of 'type-writer' fount and a foolscap page has made the volume unpleasant to read and awkward to shelve. By Stationery Office standards it seems over-priced.

\section{E. J. M. BUCKATZSCH}

\section{HUMAN RELATIONS TRAINING FOR SUPERVISORS}

THE importance of supervisory behaviour in influencing employee morale and productivity has been increasingly recognized in industry. The number of industrial concerns providing some course of training for supervisors has gradually increased, although the content and length of these training courses vary considerably from firm to firm. Recent investigations by W. H. Scott and Ian McGivering were designed to assess the extent to which they are capable of effecting change in the behaviour and relationships of supervisors in their everyday work situation (Occupational Psych., 27, No. 3 ; July 1953).

As part of their preliminary observations, they attended a series of courses provided for its supervisors by a large manufacturing concern.

The investigation was purely exploratory, yet their impressions and tentative conclusions run counter to some current assumptions about the organization and effects of supervisory training. The investigators attended five similar and consecutive courses, each lasting one week, 'sitting in' as observers; they also interviewed individually as many of the supervisors as circumstances permitted.

The supervisors' attitudes towards 'staff' specialists tended to change during the course. The tensions which frequently exist between line and 'staff' in industry have received some attention during recent 